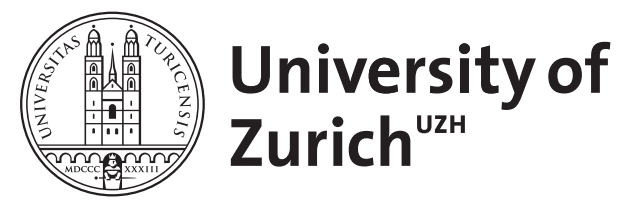

\title{
Dividend policy in Switzerland
}

\author{
Stacescu, Bogdan
}

\begin{abstract}
The paper examines dividend policy for a sample of Swiss companies. Several factors that determine cross-sectional variations in dividend policy - such as profitability, growth opportunities, and riskiness - are identified. Price volatility seems to stand out as the most significant factor. Looking at the relationship between dividends and earnings over time, dividend changes are more closely linked to past and current rather than future net income growth. However, they do confirm a persistent shift in the level of earnings. There is also a significant relationship between losses and dividend cuts. These findings suggest that it is the managers' reluctance to cut dividends that gives informational content to dividend changes
\end{abstract}

DOI: https://doi.org/10.1007/s11408-006-0013-7

Posted at the Zurich Open Repository and Archive, University of Zurich ZORA URL: https://doi.org/10.5167/uzh-156486

Journal Article

Published Version

Originally published at:

Stacescu, Bogdan (2006). Dividend policy in Switzerland. Financial Markets and Portfolio Management, 20(2):153-183.

DOI: https://doi.org/10.1007/s11408-006-0013-7 


\title{
Dividend policy in Switzerland
}

\author{
Bogdan Stacescu
}

Published online: 3 June 2006

(c) Swiss Society for Financial Market Research 2006

\begin{abstract}
The paper examines dividend policy for a sample of Swiss companies. Several factors that determine cross-sectional variations in dividend policy - such as profitability, growth opportunities, and riskiness - are identified. Price volatility seems to stand out as the most significant factor. Looking at the relationship between dividends and earnings over time, dividend changes are more closely linked to past and current rather than future net income growth. However, they do confirm a persistent shift in the level of earnings. There is also a significant relationship between losses and dividend cuts. These findings suggest that it is the managers' reluctance to cut dividends that gives informational content to dividend changes.
\end{abstract}

Keywords Dividends · Payout policy · Signaling · Expected earnings

JEL Classification Numbers $\mathrm{G} 14 \cdot \mathrm{G} 35$

\section{Introduction}

In the ideal world of Miller and Modigliani (1961), dividends are irrelevant. The value of a firm is given by its investment opportunities. Dividends are just the residual, and investors faced with consumption shocks can always get their own "homemade" dividends.

In "real life", however, dividend policy is one of the main concerns for managers and investors. Empirical studies have generally found that dividend

B. Stacescu (凶)

Swiss Banking Institute, University of Zurich,

Plattenstrasse 14, 8032 Zurich, Switzerland

e-mail: stacescu@isb.unizh.ch. 
increases are considered good news by investors, while dividend decreases lead to negative reactions.

Several explanations for the existence and importance of dividends have been suggested over the last decades. Dividends could be used as signals for the actual position of a firm. Companies could communicate their better quality by paying higher dividends: low-quality firms will not be able to imitate them since dividends involve costs in terms of foregone investment, taxes, or the need to attract external capital. Agency theory suggests that dividends may be a way to reduce the overinvestment problem or a means to keep firms in the capital markets. Dividends may also be used to attract institutional investors, who are better monitors and prefer dividends for regulatory reasons. Behavioral aspects, such as self-control, fairness, or regret aversion, may also be important parts of the picture.

Each of the main theories concerning dividend policy has found at least some support in actual data. However, empirical research has also revealed weaknesses of these explanations, and a broad consensus concerning the "best" theory of corporate payout seems far away. We may know more about the "dividend puzzle", but we are still without a definite solution.

The present paper examines some of the characteristics of dividend policy using Swiss data. The first part presents factors that influence variations in dividend payments across companies at a given point in time. The second part analyzes the changes in dividends over time.

The cross-sectional analysis for the 2000-2003 period compares the characteristics of dividend payers and non-payers. It then identifies several determinants of the differences between dividend payers in terms of payout ratios and dividend yields. The results show that companies that are less risky, larger, with lower growth opportunities, and with lower leverage tend to pay higher dividends. Institutions show a preference for dividend-paying companies, but there is little evidence that they prefer higher payout ratios or dividend yields.

Quite interestingly, the factor that turns out to have the strongest influence on payout ratios and dividend yields is price volatility. This may be interpreted as a sign that companies with higher earnings uncertainty are less likely to pay high dividends - or to pay dividends at all.

The second part of the paper then focuses on the relationship between dividends and earnings over time. Previous studies suggest that managers may target either payout ratios or dividends per share; therefore, the paper deals with both measures.

A first brief section looks at payout ratios. The Lintner model (1956) is found to perform reasonably well for a majority of companies in the sample. However, results for other companies are not so good, and very few firms actually declare they are targeting payout ratios.

Dividends per share are much more widespread as a headline indicator of dividend policy. The final section of the paper looks at changes in (split-adjusted) dividends per share and seeks to determine whether these changes have informational content. The results show that dividend increases follow periods of high earnings and cash flow growth, whereas dividend decreases follow declines. 
A closer look at the data reveals that there may nevertheless be some information conveyed by dividend changes. The average future level of earnings after dividend increases is significantly higher than the mean over the previous few years. The earnings of companies that decrease the dividend decline slightly and remain at a persistently low level around the dividend change.

Brav et al. (2004) show that while managers agree that dividends do convey information to investors, they do not think in terms of academic signaling models. Based on the results mentioned above, we could formulate an alternative explanation for the signaling value of dividends. Changes in dividend payments can be informative due to managers' reluctance to cut dividends. A dividend increase can signal management's confidence that future earnings will settle at a higher level. A dividend decrease may signal that the management thinks that earnings have indeed stabilized at a lower level and that the current level of dividends is no longer sustainable. Thus, dividend changes become informative not because they are too costly to be imitated by other companies, but because dividend decreases are costly in terms of managers' reputation.

Going on to other possible specificities of the Swiss market, it seems that, perhaps surprisingly, there is no significant connection between ownership concentration and dividend yields or payout ratios. Also, the relationship between dividend policy and firm size is only marginally significant. Thus, if one thinks of Swiss companies as being grouped into "large", widely held companies and smaller, closely held ones, the difference between the two groups in terms of dividend policy does not seem very clear-cut. One caveat about this conclusion is, however, that even the smaller companies in the sample are still "large".

The next section of the paper summarizes some of the alternative theories concerning dividends as well as previous empirical findings. Section 3 briefly presents the data, and section 4 identifies some of the sources of cross-sectional variation in dividend policy. Section 5 examines the relationship between dividends and earnings over time. The partial adjustment model of Lintner (1956) is applied to a sample of Swiss companies and is found to perform reasonably well in most cases. Section 5.2 examines the relationship between dividend changes and earnings in the surrounding years. The evidence seems to support the idea that managers will increase dividends gradually, while trying to make sure the increase is sustainable, and that they will avoid cutting dividends unless the condition of the firm worsens to a significant extent. Section 6 presents the conclusions of the paper.

\section{Motivation and related literature}

Dividend policy has long been a subject of research and debate. There are many theoretical and empirical results describing the decisions companies make in this area. At the same time, however, there is no generally accepted model describing payout policy. Moreover, empirical findings are often contradictory or difficult to interpret in light of the theory. 
In their seminal paper, Miller and Modigliani (1961) showed that under certain assumptions (perfect capital markets, rational behavior, and perfect certainty) dividends are irrelevant; all that matters is the firm's investment opportunities. A firm will always be able to compensate the cash outflow by attracting new money (via new shares or debt) if its investment program requires this.

In reality, however, people do seem to care about dividends. Lintner's (1956) classical study on dividend policy suggests that "dividends represent the primary and active decision variable in most situations". His interviews and research conducted on 28 companies showed that firms set their current dividends based on their previous history. The main decision concerned the possible change in the payment rate, and this decision was based on (expected future) earnings. Dividend policy seemed characterized by "inertia and conservatism"; managers seemed to think that investors reward stability and avoided making unsustainable changes in payout ratios. Based on these findings, Lintner suggested a model of partial adjustment to a given payout rate.

In a recent study, Brav et al. (2004) find that "maintaining the dividend level is a priority on par with investment decisions". Furthermore, less than half of the executives they interviewed agree that "the availability of good investment opportunities is an important or very important factor affecting dividend decisions". Although to a somewhat lesser degree, Lintner's findings seem valid almost half a century later.

Researchers have tried to explain the importance of dividends by looking for "imperfections" that can undermine the irrelevance proposition. Some of the most important ideas are summarized below.

An important class of models is based on the idea that the assumption of perfect information may be unrealistic and that dividends can be used as signals of firm quality. Bhattacharya (1979) builds a two-period model with two types of firms. Investments are made during the first period; their expected profitability is known to management, but not to outside investors. In order to signal the quality of their investment, the managers of "good" firms (managers are assumed to act in the interest of initial shareholders) will commit to paying high dividends in the second period. Since attracting outside financing (during the second period) is expensive due to transaction costs, "low-quality" firms will be unable to imitate "high-quality" ones. The alternative models of Miller and Rock (1985) and John and Williams (1985) consider the cost of dividends in terms of foregone investments and taxes, respectively.

The signaling models provide an explanation for the positive stock price reaction to the announcement of dividend increases or initiations. However, the empirical evidence on this hypothesis is mixed. In an early study, Watts (1973) found that unexpected changes in earnings and unexpected changes in dividends were related, although he remained skeptical about the possibility to make money by exploiting this regularity. Penman (1983) finds that "both dividend announcements and management's earnings forecasts possess information about management's expectations". Using a sample of dividend initiations and omissions, Healy and Palepu (1988) find that dividend initiations and omissions have informational content (the change in earnings is related to 
announcement-day returns, even when controlling for previous earnings), but this only holds for year 1. Yoon and Starks (1995) and Denis et al.(1994) show that dividend change announcements are linked to revisions in analysts' forecasts of current income. Nissim and Ziv (2001) control for mean reversion in earnings and show that dividend changes are useful in predicting future earnings.

On the other hand, DeAngelo et al. (1996) examine the case of companies that experience the first earnings decline after at least 9 years of sustained earnings growth. They find that more than $60 \%$ of managers still increase dividends in the year earnings decrease. Moreover, dividend changes in year 0 (the year of the earnings decline) are not related to future unexpected earnings changes. Benartzi et al. (1997) show that dividend increases are not followed by faster earnings growth. Grullon et al. (2003) challenge the findings of Nissim and Ziv (2001). They show that after controlling for the difference in the speed of adjustment following positive and negative earnings surprises, adding dividend changes into the model does not improve forecasting performance.

Based on the mixed results for the signaling theory, Grullon et al.(2002) suggest that, rather than an increase in profitability, dividend increases could reflect a decrease in risk - the "maturity hypothesis". They find that while profitability declines following a dividend increase, systematic risk in a three-factor FamaFrench model decreases. They argue that as firms become more mature (and therefore less risky, but with lower growth opportunities), they will be more likely to pay large dividends to their shareholders.

Agency theory suggests that dividends can be used as a means to control a firm's management. Distributing dividends reduces the free cash flow problem and increases the management's equity stake. Easterbrook (1984) also suggests that dividends can be used to keep firms in capital markets, where they are monitored by potential investors. This is useful since monitoring by existing shareholders can be hindered by coordination problems. Lang and Litzenberger (1989) find that dividend increases are associated with higher positive share price reactions for companies with Tobin's $q$ smaller than unity, i.e., for companies with lower growth opportunities.

Another agency problem is that between shareholders and debtholders. The risk that shareholders will expropriate debtholders by paying themselves excessive dividends has led to the often-encountered covenants restricting dividend policy in bond contracts. Hadjinicolaou and Kalay (1984) and Maxwell and Stephens (2003) examine the reaction of stock and bond prices to dividend announcements. They find that although dividend increases are more favorable to shareholders, the overall value of the firm goes up - thus there is an information effect beside the possible wealth transfer.

Allen et al.(2000) suggest that dividends can be used to attract institutional investors, who do not pay dividend taxes and have to invest in dividend-paying companies for regulatory reasons. The firm will benefit from attracting this particular type of investor since they are better monitors and can trade large blocks of shares more easily. In an empirical study, Grinstein and Michaely (2005) find that institutions do choose dividend-paying companies; however, they show no preference for higher dividend yields. 

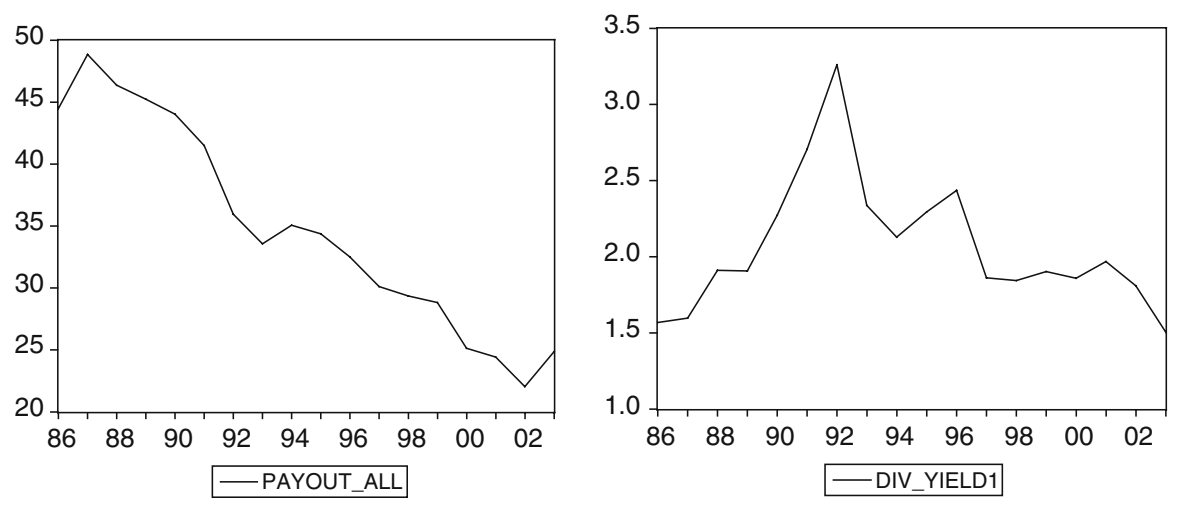

Fig. 1 Left average payout ratio; right average dividend yield over the 1986-2003 period for all available observations in Datastream

Baker and Wurgler (2004) put forward a "catering theory" of dividends. They build a measure indicating investors' preference for dividends and show that firms' dividend policies follow this preference.

To sum up, there are several potential explanations for the existence of dividends, although none of them is generally accepted or beyond criticism. The Miller and Modigliani proposition of dividend irrelevance is still often mentioned, as is the idea of a "dividend puzzle".

\section{Data}

The paper uses data on listed Swiss companies over the 1974-2004 period. The main data source is Datastream; annual reports have also been used (for instance to get information on the main shareholders). Data on repurchases are taken from Compustat Global Vantage. Foreign companies listed in Switzerland have been excluded from the sample. Financial companies and utilities are also excluded. This is current practice in empirical literature, since it is generally assumed that the different regulatory environment of these companies could influence dividend policy. Moreover, in the case of the Swiss sample, a large proportion of the financial companies with available data are cantonal banks, which can be considered difficult to compare to purely private, non-financial companies. As a result, there are 175 non-financial, non-utility companies in the overall sample. Because of limited data availability, smaller samples are used in some of the following sections.

Unlike American companies, which pay dividends on a quarterly basis, Swiss companies usually pay dividends only once a year. (Ex-dividend days are usually in May or June.) Thus, the analysis in this paper uses yearly observations. This has the obvious disadvantage of reducing the number of data points. On the other hand, studies such as Lintner (1956) and DeAngelo et al. (1992) argue that the main horizon for dividend policy is the whole year even in the American case. 

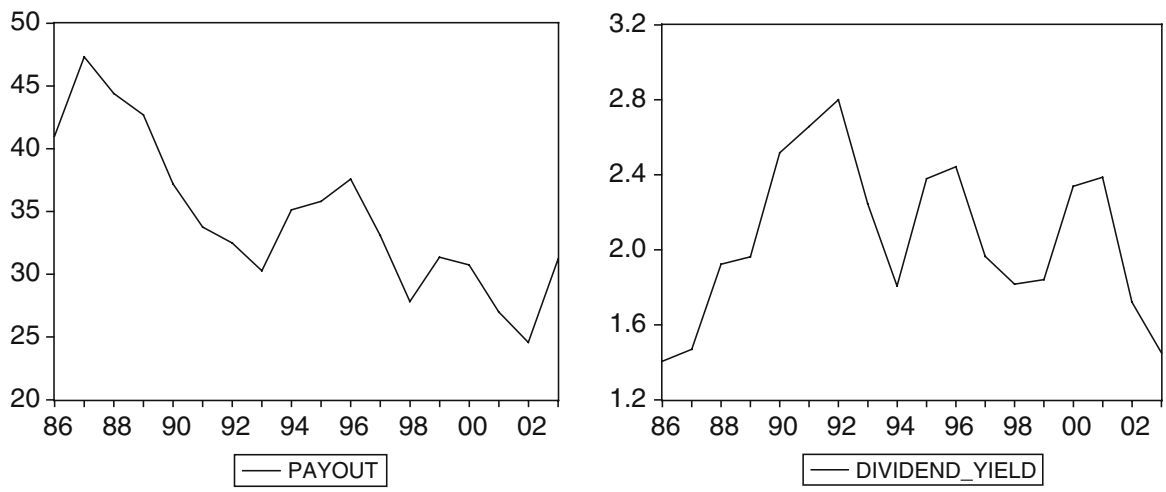

Fig. 2 Left average payout ratio; right average dividend yield for 40 companies with continuous data over the 1986-2003 period

Figures 1 and 2 present payout ratios and dividend yields over the 1986-2003 period. The mean payout ratio was $30.99 \%$, while the mean dividend yield was $1.96 \%$. Payout ratios had a decreasing trend over the interval - a tendency that is also reported for the USA (Allen and Michaely 2002; Brav et al. 2004) as well as other countries (Osobov 2004). Dividend yields did not have any definite trend; their movement is influenced by both changes in dividends and movements in share prices.

\section{Cross-sectional comparisons of dividend payments}

This part of the paper examines the factors that determine variations in dividend policy across firms. The comparison is based both on averages for the 2000-2003 period and on data for the single year 2003.

There are several groups of variables that are considered in the cross-sectional comparisons:

- Market-to-book ratios, as a proxy for growth opportunities. Since low market-to-book companies are more likely to have free cash flow problems, it is to be expected that they pay (higher) dividends.

- Total assets and total sales, as proxies for firm size. Large companies are usually "mature" companies and therefore have more available cash relative to their positive NPV projects. Moreover, they are more likely to have widely dispersed shareholdings, and dividends could be used as a way to "keep" firms "in the capital markets" in order to enhance monitoring. At the same time, however, large companies are usually considered less informationally opaque than small companies, and so there may be less need for dividends as costly signals. Thus, observing the actual connection between firm size and dividend policy can be interesting.

- The firms' betas and price volatility (computed as the band within which the share price moved around the mean price during the year), as measures 
of firm risk. The "maturity hypothesis" suggests that dividend increases are associated with decreases in risk rather than increases in profitability. Also, risk is an important firm characteristic in itself, and it is important to control for it.

- Capital gearing, as a measure of leverage in book terms. Debt covenants often include limits concerning dividend payments as a way to mitigate the agency problem between shareholders and debtholders. On a different level, both debt and dividends can be used to reduce the free cash flow problem. Johnson (1995) suggests that debt and dividends could be alternative means to control management.

- Returns on assets and returns on equity, as measures of firm profitability. While it may seem obvious that more profitable companies will pay higher dividends, it is important to control for this measure while examining the impact of the other factors.

- Several indicators for the ownership structure of these companies. The ownership of large Swiss companies is quite varied - from family-owned companies to widely-held ones, or companies owned by investment funds. Thus, it is interesting to examine the impact of the ownership structure on dividend policy.

\subsection{Who pays dividends?}

There are several features that distinguish firms that pay dividends from firms that do not. The analysis in this subsection focuses on the 2000-2003 period and distinguishes between companies that had at least one dividend payment over the 4 years and companies that had none. Table 1 summarizes some of the main features of the two groups.

Not surprisingly, companies that paid dividends over the 2000-2003 period had significantly higher profitability than companies that did not. It is interesting to note that non-paying companies made losses on average, whereas companies that paid dividends had positive mean returns on assets and equity.

Non-paying firms had a higher market-to-book ratio. Indeed, agency theory suggests that companies with better growth opportunities (proxied by the market-to-book ratio) are less likely to have free cash flow problems. Therefore, dividends as an instrument to discipline management are less useful to these companies. The fact that leverage is virtually identical for the two groups of companies may mean that dividends and debt are used in different ways to control management, as suggested by Johnson (1995).

Companies that did not pay dividends over the four years also featured higher price volatility and higher betas. They also tended to have lower total assets and lower sales (although the difference is not significant for the latter). Together with the higher market-to-book ratio, these differences give support to the "maturity hypothesis" of Grullon et al. (2002): companies that are younger and riskier tend to pay lower dividends. 
Table 1 Comparison between dividend-paying and non-paying companies, 2000-2003

\begin{tabular}{llll}
\hline Variable & $\begin{array}{l}\text { Mean } \\
\text { ("paying") } \\
\text { (group) }\end{array}$ & $\begin{array}{l}\text { Mean } \\
\text { ("non-paying") } \\
\text { (group) }\end{array}$ & $p$ values \\
\hline Mean market-to-book ratio, 2000-2003 & 2.226 & 3.401 & 0.052 \\
Mean returns on assets, 2000-2003 & 5.093 & -4.566 & 0.000 \\
Mean returns on equity, 2000-2003 & 10.893 & -21.359 & 0.000 \\
Mean capital gearing, 2000-2003 & 37.770 & 37.120 & 0.881 \\
Beta coefficient & 0.86 & 1.33 & 0.009 \\
Mean price volatility, 2000-2003 & 24.740 & 38.250 & 0.000 \\
Mean total assets, 2000-2003 (CHF, thousands) & $4,643,377$ & $1,484,523$ & 0.108 \\
Mean sales, 2000-2003 (CHF, thousands) & $3,017,036$ & 467,396 & 0.184 \\
Mean foreign-owned share of capital, 2001-2003 & 8.08 & 15.42 & 0.081 \\
Mean share of capital owned by institutions, 2001-2003 & 3.61 & 1.81 & 0.648 \\
Share of capital owned by large shareholders, 2003 & 46.03 & 41.78 & 0.412 \\
Share of voting rights for large shareholders, 2003 & 42.19 & 40.34 & 0.780 \\
\hline
\end{tabular}

Ownership concentration does not seem to affect the option to pay dividends. This conclusion holds whether one considers the share of voting rights or the share of the equity owned by large shareholders (shareholders that have more than $5 \%$ of a company's voting rights and that are obliged to make their ownership public under Swiss regulations). Two other aspects concerning ownership seem to be more closely related with the decision to pay dividends. Institutional investors (investment companies and pension funds) held larger shares in dividend-paying companies, but overall the difference is not significant. (Pension funds taken separately did show a clear preference for dividend-paying companies, perhaps for regulatory reasons.) This finding is consistent with results from previous papers, such as Grinstein and Michaely (2005). Dividend-paying companies also had a lower foreign-owned share of capital.

Based on these results and a look at the overall sample, one can conclude that companies that do not pay dividends tend to be either old companies, established companies going through protracted difficulties, or - more often younger, smaller, and riskier companies.

\subsection{Sources of cross-sectional variation}

This section focuses on the relationship between payout ratios and the variables described above over the 2000-2003 period. It also presents separately the results for the subsample of companies that had at least one dividend payment in one of the 4 years. As will be shown below, the relationship between dividend payments and many of the selected variables is not always monotonic. Results for previous years are also presented in order to check the persistence of the relationships found for the more recent period. To avoid cluttering the presentation, the largely similar findings using dividend yield (as alternative 
measure of dividend policy) are not reported. The more important differences are discussed at the end of the section.

Table 2 shows that, for the whole set of firms, more profitable companies have higher payout ratios. Taking into account just the group of companies with positive dividend payments, however, the relationship is much weaker, especially for returns on equity.

The fact that companies with higher price volatility and higher market-tobook ratios have lower dividend yields and payout ratios supports the "maturity hypothesis" of Grullon et al. (2002). "Younger" (smaller, riskier, growing) companies pay less dividends than "older" ones. One could note, however, that correlations with firm size are not significant in this sample; so one should be careful in drawing the picture of the standard "life-cycle" of a firm. The results concerning riskiness can also be related to Lintner's (1956) finding that managers are reluctant to increase dividends if they are not sure that future earnings will be stable enough to prevent dividend decreases.

Capital gearing is negatively correlated with the payout ratio. It may be the case that highly levered firms find additional debt very expensive and try to increase their retained earnings. Debt covenants also usually include restrictions on dividend payments. It is interesting to note that in a US study, DeAngelo et al.(2004) find a positive relationship between leverage and dividends. This suggests that high dividends and high leverage are used together in the case of companies with potential free cash flow problems. (One can also note that

Table 2 Payout ratios and firm characteristics

\begin{tabular}{|c|c|c|c|c|}
\hline Variables & $\begin{array}{l}\text { Correlation } \\
\text { (averages } \\
2000-2003 \text { ) }\end{array}$ & Correlation & $\begin{array}{l}\text { Correlation - } \\
\text { "paying" } \\
\text { subsample } \\
\text { (averages } \\
2000-2003 \text { ) }\end{array}$ & $\begin{array}{l}\text { Correlation - } \\
\text { "paying" } \\
\text { subsample } \\
(2003)\end{array}$ \\
\hline Market-to-book ratio & $-0.188 * * *$ & -0.001 & -0.114 & -0.028 \\
\hline Returns on assets & $0.337 * * *$ & $0.419 * * *$ & $0.266 * *$ & $0.205 * *$ \\
\hline Returns on equity & $0.199 * *$ & $0.332 * * *$ & 0.006 & -0.063 \\
\hline Sales & 0.063 & 0.050 & 0.028 & 0.068 \\
\hline Total assets & 0.067 & 0.066 & 0.033 & 0.076 \\
\hline Capital gearing & -0.132 & $-0.176 * *$ & $-0.196 * *$ & $-0.238 * * *$ \\
\hline Price volatility & $-0.497 * * *$ & $-0.375 * * *$ & $-0.407 * * *$ & $-0.287 * * *$ \\
\hline $\begin{array}{l}\text { Voting rights of large } \\
\text { shareholders }(2003)\end{array}$ & -0.004 & -0.029 & 0.030 & -0.016 \\
\hline $\begin{array}{l}\text { Capital share of } \\
\text { large shareholders (2003) }\end{array}$ & -0.032 & -0.011 & -0.015 & -0.068 \\
\hline $\begin{array}{l}\text { Share of capital owned } \\
\text { by families and employees }\end{array}$ & -0.096 & -0.074 & -0.121 & -0.164 \\
\hline Foreign-owned share of capital & -0.096 & -0.014 & $0.194 * *$ & 0.107 \\
\hline Share of capital owned by institutions & -0.036 & -0.094 & -0.032 & 0.019 \\
\hline Dividend yield & $0.633 * * *$ & $0.537 * * *$ & $0.418 * * *$ & $0.367 * * *$ \\
\hline
\end{tabular}

\footnotetext{
* Significant at the $10 \%$ level;

** Significant at the $5 \%$ level;

*** Significant at the $1 \%$ level
} 
dividend payments automatically increase leverage by reducing equity and total assets.) The relationship found in the Swiss sample can be taken to suggest a higher influence of debt covenants and the use of debt and dividends as substitutes rather than complements in solving agency problems, as found in Johnson (1995).

Dividend policy does not appear to be strongly affected by ownership structure. The relationship between ownership concentration (the share of capital or voting rights owned by large shareholders) and dividend policy is inconclusive (usually negative and insignificant for the payout ratio and positive and insignificant for the dividend yield). As may be expected, there is a negative correlation between the share of capital owned by families (and employees) and the two measures of dividend policy - but the relationship is again not significant. While foreign participation in companies that made no dividend payments over the period was higher than in the dividend-paying companies, within the latter group foreign investors seem to prefer companies with higher payout ratios.

There is also a positive and significant relationship between dividend yields and payout ratios. While the relationship is hardly surprising, it shows that one of the reasons for higher dividend yields is that companies pay a higher share of their earnings as dividends.

The simple analysis of correlations allows us to determine several factors affecting dividend policy. These findings can be checked using regression analysis. The multivariate results show that the variables outlined above explain part of the variability in dividend policy across firms. Robust (White) residuals were used to avoid heteroskedasticity problems.

Table 3 presents the main factors influencing payout ratios at three points in time: 1993, 1998, and 2003. Payout ratios are regressed on lagged measures of profitability, leverage, risk, size, growth opportunities, and ownership concentration. The first 2 years are characterized by a growing economy and increasing share prices (the more so for the second period) and thus complement the picture provided by the more recent years of declining share prices and low economic growth ${ }^{1}$. An important caveat is that going back towards the early 1990s reduces data availability and the sample size. Since reporting major shareholdings has only been mandatory in Switzerland since 2002, the regression for 2003 is the only one that includes a measure of ownership concentration.

In all 3 years, profitability is positively associated with payout ratios. The relationship is weaker during the periods of higher economic growth - when growth opportunities are larger and the opportunity cost of dividends increases.

Leverage is negatively related to the payout ratio, just as the previous correlation analysis suggested. The relationship is not significant for 1998, suggesting that debt covenants are less likely to become binding during a period of higher growth.

\footnotetext{
1 The author would like to thank an anonymous referee for emphasizing the importance of this point
} 
Table 3 Factors influencing the payout ratio Dependent variable: payout ratio in 2003

\begin{tabular}{|c|c|c|c|c|}
\hline \multirow[t]{2}{*}{ Variables } & \multicolumn{4}{|c|}{ Coefficients ( $p$ values) } \\
\hline & 1993 & 1998 & 2003 & 2003 \\
\hline Constant & $\begin{array}{l}70.871 \\
(0.000)\end{array}$ & $\begin{array}{l}57.276 \\
(0.000)\end{array}$ & $\begin{array}{l}46.428 \\
(0.000)\end{array}$ & $\begin{array}{l}42.045 \\
(0.000)\end{array}$ \\
\hline $\operatorname{ROA}(\mathrm{t}-1)$ & $\begin{array}{l}0.710 \\
(0.115)\end{array}$ & $\begin{array}{l}0.301 \\
(0.197)\end{array}$ & $\begin{array}{l}0.511 * * * \\
(0.004)\end{array}$ & $\begin{array}{l}0.558 * * * \\
(0.000)\end{array}$ \\
\hline Capital gearing $(\mathrm{t}-1)$ & $\begin{array}{l}-0.519 * * * \\
(0.007)\end{array}$ & $\begin{array}{l}-0.176 \\
(0.221)\end{array}$ & $\begin{array}{l}-0.203^{*} \\
(0.081)\end{array}$ & $\begin{array}{l}-0.202 * * \\
(0.048)\end{array}$ \\
\hline Price volatility $(\mathrm{t}-1)$ & $\begin{array}{l}-0.913^{* *} \\
(0.022)\end{array}$ & $\begin{array}{l}-0.394 * \\
(0.054)\end{array}$ & $\begin{array}{l}-0.452 * \\
(0.076)\end{array}$ & $\begin{array}{l}-0.381 * \\
(0.064)\end{array}$ \\
\hline Total assets (in billions; $\mathrm{t}-1$ ) & $\begin{array}{l}-0.280 \\
(0.192)\end{array}$ & $\begin{array}{l}0.020 \\
(0.859)\end{array}$ & $\begin{array}{l}0.220^{*} \\
(0.059)\end{array}$ & $\begin{array}{l}0.017 * * * \\
(0.009)\end{array}$ \\
\hline Market-to-book ratio $(\mathrm{t}-1)$ & $\begin{array}{l}-0.913^{* * *} \\
(0.022)\end{array}$ & $\begin{array}{l}-1.495 * \\
(0.097)\end{array}$ & $\begin{array}{l}-0.662 \\
(0.176)\end{array}$ & $\begin{array}{l}-0.492 \\
(0.312)\end{array}$ \\
\hline Voting rights (large shareholders, 2003) & & & $\begin{array}{l}-0.017 \\
(0.835)\end{array}$ & \\
\hline Adjusted $R^{2}$ & 0.244 & 0.146 & 0.164 & 0.185 \\
\hline Number of observations & 59 & 64 & 71 & 97 \\
\hline
\end{tabular}

* Significant at the $10 \%$ level;

** Significant at the $5 \%$ level;

*** Significant at the $1 \%$ level

Price volatility and the market-to-book ratio both have a negative impact on payout ratios, but the effect of the former seems to be stronger. The relationship with firm size (proxied by total assets) is generally weak, except for the smaller sample from 2003.

As expected from previous results, ownership concentration does not have a significant influence on payout ratios. While the sign is indeed negative - the work of La Porta et al. (2000), for instance, suggests such a relationship - the relationship is extremely weak. This is confirmed by the results of Goergen et al. (2003) for Germany.

Compared to payout ratios, dividend yields show a weaker relationship with profitability and leverage. While price volatility is an important factor for explaining payout ratios, it is even more so for dividend yields. These findings are not surprising, since the dividend yield generally has a negative relationship with growth opportunities. The relationship with the ownership measures is again weak. The explanatory power of the analogous regressions for the dividend yield is higher.

To summarize, more profitable, less risky, larger, less leveraged companies with lower growth opportunities pay more dividends. Price volatility appears to be a really important factor in the cross-sectional variation in dividend policy. The explanation for this may be that when future earnings are uncertain, managers are unwilling to commit to large cash payouts for the future. Dividend policy seems to be surprisingly uniform across different ownership structures, a finding which is quite interesting for a Swiss sample. 


\subsection{A note on repurchases}

A final point in the cross-sectional analysis concerns the relationship between dividends and repurchases. Data on repurchasing activity are based on the "Purchase of stock" item from Compustat.

It seems that, as in the American case, repurchases are becoming an increasingly popular method to disburse cash to shareholders, although they seem to still be less widespread in Switzerland (see also Dumont et al. 2004). However, since the data for this subsection is rather sparse, the results should be interpreted with care. Table 4 presents the relationship between payout policy and the profitability and price volatility of the companies in the sample. There are four groups of firms: those that neither paid dividends nor repurchased shares over the 2000-2002 period (16 companies), those that only repurchased shares (4 companies), those that only paid dividends (73 companies), and those that chose both types of payouts (15 companies).

While companies that did not pay any cash or just repurchased shares made losses on average, companies that paid dividends had positive mean profits with the most profitable group using both types of payments. Price volatility shows the opposite pattern. The last column shows the $\mathrm{p}$-values for the ANOVA test for the equality of the means for the four groups. The results suggest that the differences are significant.

There seem to be no significant differences in terms of ownership concentration and firm size between the four groups. Companies that did not pay any cash had higher market-to-book ratios than those that paid dividends, but companies that only used repurchases had lower ratios (since the "repurchase-only" subsample has just four companies, it is difficult to draw a definite conclusion based on this result).

One can tentatively conclude that companies with stable positive earnings generally choose dividends (with the most profitable and least risky companies choosing both types of payment). Companies with low and volatile earnings (and perhaps higher growth opportunities) choose to pay out no cash or to use just repurchases. This pattern is in line with the findings of Jagannathan et al. (2000), Guay and Harford (2000), and Fama and French (2001) for the USA.

Table 4 Dividends and repurchases

\begin{tabular}{lccccc}
\hline Variable & No payment & Repurchases & Dividends & $\begin{array}{l}\text { Dividends and } \\
\text { repurchases }\end{array}$ & $\begin{array}{l}p \text { value, } \\
\text { ANOVA test }\end{array}$ \\
\hline ROA & -15.603 & -12.332 & 3.494 & 5.200 & 0.004 \\
ROE & -30.937 & -13.552 & 6.087 & 10.506 & 0.002 \\
Price volatility & 35.408 & 35.442 & 23.393 & 19.067 & 0.003 \\
\hline
\end{tabular}

The table presents the average levels of returns on assets, returns on equity and price volatility over the 2000-2002 period for four groups of companies: those that did not repurchase shares and did not pay dividends over the 3 years, those that only repurchased shares, those that only paid dividends, and those that disbursed cash using both methods 
It confirms that there are significant differences between dividends and repurchases, and that there is more at work than the "substitution" process described by Grullon and Michaely (2002).

\section{The dynamic aspect: dividends and earnings}

This part of the paper deals with variations in dividends over time. It focuses on the relationship between dividends and earnings, and explores the reasons for changes in dividends for a given company.

Brav et al.(2004) find in their survey of US financial executives that $40 \%$ of them target dividends per share, $28 \%$ target dividend payout ratios, and $27 \%$ target growth in dividends per share. Section 5.1 examines the importance of dividend payout ratios based on the Lintner model. Section 5.2 then looks at changes in dividends per share and their informational content.

\subsection{The Lintner model and payout targets}

As a general rule, dividend policy seems to be fairly stable over time. For instance, adding lagged measures of the payout ratio or the dividend yield to the regressions in the previous section shows that they are highly significant and improves the explanatory power of the regressions by a large amount. Lintner (1956) suggests that managers set targets concerning payout ratios and adjust dividend payments in order to gradually reach that target. Under this hypothesis, the target ratio $(\gamma)$ is given by

$$
D_{t}^{*}=\gamma E_{t},
$$

and the adjustment equation is

$$
D_{t}-D_{t-1}=\alpha+\delta\left(D_{t}^{*}-D_{t-1}\right)+u_{t},
$$

where $D_{\mathrm{t}}$ are dividends paid in year $\mathrm{t}, E_{t}$ are earnings for the same year, and $D_{\mathrm{t}}^{*}$ is the desired level of dividends in year t.

Combining the two equations, the model proposed by Lintner can be written as

$$
\Delta D_{t}=\alpha+\beta_{1} D_{t-1}+\beta_{2} E_{t}+u_{t} .
$$

The change in dividends is thus modeled as a function of lagged dividends and current earnings. Managers are supposed to have in mind a "target" payout ratio, and they slowly adjust dividends in order to reach this target. The adjustment is gradual since, as Lintner finds, managers want to make sure that changes in earnings are lasting, and they will avoid making decisions that will have to be reversed soon. 
Equation (3) is a partial adjustment model, which can be consistently estimated by ordinary least squares. The target payout ratio is estimated as $-\beta_{2} / \beta_{1}$, while the speed of adjustment is given by $-\beta_{1}$.

Estimating the Lintner model requires data over a longer period of time. As a result, the sample is reduced to 60 companies for the 1987-2003 period (16 years). The results of estimating the partial adjustment model for each of the companies are summarized in Table 5.

The mean target ratio is around one-third, while the median is around onefifth. The actual mean payment ratio for the companies in the sample is $30.99 \%$, while the median is $30.32 \%$. Thus, estimated target payout ratios are close to the actual ones, and the explanatory power of the model is high (the average adjusted $R^{2}$ s are above $40 \%$ ). There is no significant autocorrelation in any of the regressions. Results are also quite similar if one looks at the 25 companies that had data for the longer 1975-2003 period.

For all US companies with valid Compustat data, Brav et al. (2004) find average payout ratios of 37,17 , and $8 \%$ for the $1950-1964,1965-1983$, and 1984-2002 periods, respectively. The mean speed of adjustment was $0.67,0.4$, and 0.33 over the three successive intervals. (Lintner's estimates suggest a target payout ratio of around $50 \%$.) Given the low explanatory power and the high variability in terms of estimated target payout ratios, Brav et al. suggest that the relationship suggested by Lintner may have grown weaker over time. It is known that payout ratios have declined over time in the USA; Swiss data seem to suggest a similar trend (the average payout ratio for the companies in the sample decreased from $46.28 \%$ in 1987 to $25.11 \%$ in 2003). Moreover, while the overall results look good on average for the Swiss sample, there is once again considerable variability at the firm level. The model performs better for some companies than for others. Adjusted $R^{2}$ s vary from a low of $-0.09 \%$ to a high of $99 \%$. The bulk of the firms are, however, somewhere between 20 and $70 \%$.

It is also important to note that out of the 60 Swiss companies in the sample, only four stated in their annual report for 2003 that they target the payout ratio. The range the four companies gave for the target was between 25 and 33\% - a number which is close to the estimated mean and median targets for the sample. The partial adjustment model, however, did not perform well for three out of the four companies. At least in the Swiss case, it seems that when the management actually declares a formal target ratio, this is more a kind of signal for future dividend policy rather than a description of current realizations.

To sum up, there seems to be evidence that payout ratios are relatively stable over time or that they change gradually. The practice of formally targeting a

Table 5 Estimation results for the partial adjustment model for the payout ratio (60 companies, 1987-2003)

\begin{tabular}{llll}
\hline & Speed of adjustment & Target payout ratio & Adjusted $R^{2}$ \\
Mean & 0.66 & 0.33 & 0.43 \\
Median & 0.63 & 0.20 & 0.48 \\
Standard deviation & 0.40 & 0.52 & 0.26 \\
\hline
\end{tabular}


particular payout ratio, however, is not very widespread. Managers seem to concentrate mainly on dividends per share, which is the focus of the following section.

\subsection{Dividends and past, current and future earnings}

\subsubsection{Empirical findings on the informational content of dividend changes}

Many models suggest that dividends are costly signals of future profitability. This can explain both why dividends are paid in spite of the tax advantage of capital gains and why announcements of dividend increases are usually accompanied by positive share price reactions. As we have seen in section 2, however, the empirical evidence about the signaling idea is quite mixed.

\subsubsection{Dividend changes and earnings}

This section examines the relationship between dividend changes and changes in earnings. The year of the dividend change is defined as year 0 ; the previous 3 years are years -3 to -1 ; the following three are years 1 to 3 . The sample is based on non-financial, non-utility Swiss companies for which data were available for the period 1982-2003. The resulting sample contains 409 dividend increases, 65 dividend decreases, 44 dividend omissions, as well as 117 cases in which there was no dividend payment for the second consecutive year, 25 cases when companies resumed dividend payments, and 271 cases when dividends remained unchanged. Since dividend increases are by far the largest group, they are analyzed both as a whole and separately for each quintile of dividend changes. The changes in earnings for each group (as well as the changes in several other variables) are compared to the changes for companies that kept dividends constant - these companies form the "control group" in the study. Comparisons to zero are also presented whenever they are relevant (to test, for instance, whether earnings have remained flat between two periods).

Dividends are assigned to year $t$ if they are declared in that particular year (and paid from the net income of year $t-1$ ). The earnings and cash flow figures are those reported for the year. Total assets for year $t$ are as reported at the end of the year. The change in dividends in computed as

$$
\Delta D_{0 / 1}=\frac{D_{0}-D_{-1}}{D_{-1}}
$$

where $\mathrm{D}_{0}$ are (split-adjusted) dividends per share announced in year 0 , and $D_{-1}$ are dividends announced in year -1 . If there was no dividend payment in the previous year (the denominator is zero), two separate groups are created for companies that resume payments and companies that continue not to pay dividends. 
Table 6 presents the relationship between dividend changes and changes in earnings per share between years 0 and 1 (all earnings indicators are normalized by total assets per share at the end of year -1 ). One can see that dividend changes do not appear to predict future earnings growth. Companies that have increased dividends do not seem to grow faster; in fact, the mean and median of their earnings increase are quite similar to that of companies that did not pay dividends in either year. Results are quite similar if one takes the earnings growth between years 0 and 3 or between years 1 and 3 (not reported). There also seems to be no obvious connection between dividend changes and changes in earnings between years -1 and 0 ("current changes"). Indeed, the only strong

Table 6 Dividend changes and future earnings changes

\begin{tabular}{|c|c|c|c|c|c|c|}
\hline Type & Mean & Median & $\begin{array}{l}p \text { value, } \\
\text { mean } \\
\text { compared } \\
\text { to } 0\end{array}$ & $\begin{array}{l}p \text { value, } \\
\text { mean } \\
\text { compared } \\
\text { to the no } \\
\text { change } \\
\text { group }\end{array}$ & $\begin{array}{l}p \text { value, } \\
\text { median } \\
\text { compared } \\
\text { to the no } \\
\text { no change } \\
\text { subsample } \\
\text { (Wilcoxon test) }\end{array}$ & $\begin{array}{l}p \text { value, } \\
\text { median } \\
\text { compared } \\
\text { to the } \\
\text { change } \\
\text { subsample } \\
\left(\chi^{2} \text { test }\right)\end{array}$ \\
\hline Omissions & 0.06708 & 0.01208 & 0.1440 & 0.1413 & 0.0606 & 0.1858 \\
\hline $\begin{array}{l}\text { Continued } \\
\text { omissions }\end{array}$ & 0.00711 & 0.00692 & 0.3024 & 0.2138 & 0.0406 & 0.1504 \\
\hline Decreases & 0.00346 & 0.00237 & 0.5556 & 0.4907 & 0.8892 & 0.8902 \\
\hline No change & -0.00363 & 0.00187 & 0.4553 & & & \\
\hline \multicolumn{7}{|l|}{ Increases } \\
\hline$Q 1$ & 0.00999 & 0.00606 & 0.0278 & 0.1323 & 0.0625 & 0.0754 \\
\hline$Q^{2}$ & 0.00916 & 0.00506 & 0.2853 & 0.2029 & 0.4047 & 0.1197 \\
\hline$Q 3$ & 0.00309 & 0.00571 & 0.6636 & 0.4848 & 0.3138 & 0.1972 \\
\hline$Q^{4}$ & -0.00773 & 0.00058 & 0.1921 & 0.6629 & 0.2900 & 0.5266 \\
\hline$\widetilde{Q 5}$ & -0.00680 & 0.00004 & 0.3293 & 0.7403 & 0.6490 & 0.4673 \\
\hline All increases & 0.00157 & 0.00350 & 0.6006 & 0.3348 & 0.4747 & 0.3086 \\
\hline \multirow{2}{*}{$\begin{array}{l}\text { Resumed } \\
\text { payments }\end{array}$} & 0.00126 & 0.00449 & 0.9199 & 0.7651 & 0.8662 & 0.8344 \\
\hline & $\begin{array}{l}p \text { value, } \\
\text { mean }\end{array}$ & & $\begin{array}{l}\text { median } \\
\text { (Wilcoxon test) }\end{array}$ & & $\begin{array}{l}p \text { value, } \\
\text { median }\left(\chi^{2} \text { test }\right)\end{array}$ & \\
\hline $\begin{array}{l}\text { Increases versus } \\
\text { decreases }\end{array}$ & 0.8099 & & 0.7640 & & 0.5044 & \\
\hline $\begin{array}{l}\text { Increases versus } \\
\text { resumed payments }\end{array}$ & 0.9804 & & 0.6292 & & 0.8368 & \\
\hline $\begin{array}{l}\text { Resumed payments } \\
\text { versus continued } \\
\text { omissions }\end{array}$ & 0.7141 & & 0.2451 & & 0.5086 & \\
\hline
\end{tabular}

The table presents the relationship between changes in dividends per share and changes in earnings per share between years 0 and 1 , normalized by total assets per share at the end of year -1 . Observations are grouped according to the sign and size of the change in dividends per share: omissions, continued omissions (when no dividends are paid following a dividend omission), renewed payments, decreases, no change, and the quintiles of dividend increases. The mean and median earnings changes for each group are then compared to zero and to their counterparts from the "no change group 
result is that companies that do not pay dividends in both year -1 and year 0 exhibit higher current earnings growth.

This is troubling evidence for the idea that companies that increase dividends do so in order to signal higher earnings growth in the future. Although surprising, the result does confirm previous findings. In their study based on US data, Benartzi, Michaely, and Thaler (1997) show that dividend changes are connected with past and to some extent current earnings changes, but there is no significant relationship with future movements in earnings.

A look at the Swiss data confirms the strong relationship between past earnings and dividend changes. Table 7 shows that the different groups registered markedly different earnings changes between years -2 and -1 . (It is perhaps

Table 7 Dividend changes and past earnings changes

\begin{tabular}{|c|c|c|c|c|c|c|}
\hline Type & Mean & Median & $\begin{array}{l}p \text { value, } \\
\text { mean } \\
\text { compared } \\
\text { to } 0\end{array}$ & $\begin{array}{l}p \text { value, } \\
\text { mean } \\
\text { compared } \\
\text { to the no } \\
\text { change } \\
\text { subsample }\end{array}$ & $\begin{array}{l}p \text { value, } \\
\text { median } \\
\text { compared } \\
\text { to the } \\
\text { no change } \\
\text { subsample } \\
\text { (Wilcoxon test) }\end{array}$ & $\begin{array}{l}p \text { value, } \\
\text { median } \\
\text { compared } \\
\text { to the } \\
\text { no change } \\
\text { subsample } \\
\left(\chi^{2} \text { test }\right)\end{array}$ \\
\hline Omissions & -0.03851 & -0.00104 & 0.0228 & 0.0000 & 0.0001 & 0.0037 \\
\hline $\begin{array}{l}\text { Continued } \\
\text { omissions }\end{array}$ & 0.03245 & 0.00481 & 0.0247 & 0.0003 & 0.0002 & 0.0057 \\
\hline Decreases & -0.10919 & -0.00624 & 0.0013 & 0.0790 & 0.0332 & 0.0038 \\
\hline No change & -0.00365 & -0.00104 & 0.0510 & & & \\
\hline \multicolumn{7}{|l|}{ Increases : } \\
\hline Q1 & 0.00611 & 0.00421 & 0.0235 & 0.0080 & 0.0000 & 0.0000 \\
\hline Q2 & 0.00308 & 0.00521 & 0.0791 & 0.0592 & 0.0000 & 0.0000 \\
\hline Q3 & 0.00946 & 0.00779 & 0.0000 & 0.0002 & 0.0000 & 0.0000 \\
\hline Q4 & 0.00964 & 0.00957 & 0.0028 & 0.0006 & 0.0000 & 0.0000 \\
\hline Q5 & 0.00296 & 0.01789 & 0.0000 & 0.0000 & 0.0000 & 0.0000 \\
\hline All increases & 0.01161 & 0.00705 & 0.0000 & 0.0000 & 0.0000 & 0.0000 \\
\hline \multirow{2}{*}{$\begin{array}{l}\text { Resumed } \\
\text { payments }\end{array}$} & 0.00174 & 0.01029 & 0.0759 & 0.0020 & 0.0005 & 0.0066 \\
\hline & $\begin{array}{l}p \text { value, } \\
\text { mean }\end{array}$ & & $\begin{array}{l}p \text { value, median } \\
\text { (Wilcoxon test) }\end{array}$ & & $\begin{array}{l}p \text { value, median } \\
\left(\chi^{2} \text { test }\right)\end{array}$ & \\
\hline $\begin{array}{l}\text { Increases versus } \\
\text { decreases }\end{array}$ & 0.0000 & & 0.0000 & & 0.0000 & \\
\hline $\begin{array}{l}\text { Increases versus } \\
\text { resumed payments }\end{array}$ & $\begin{array}{l}0.3552 \\
\text { s }\end{array}$ & & 0.3101 & & 0.1493 & \\
\hline $\begin{array}{l}\text { Resumed payments } \\
\text { versus continued } \\
\text { omissions }\end{array}$ & 0.6308 & & 0.5486 & & 0.1230 & \\
\hline
\end{tabular}

The table presents the relationship between changes in dividends per share and changes in earnings per share between years -2 and -1 , normalized by total assets per share at the end of year -1 . Observations are grouped according to the sign and size of the change in dividends per share: omissions, continued omissions (when no dividends are paid following a dividend omission), renewed payments, decreases, no change, and the quintiles of dividend increases. The mean and median earnings changes for each group are then compared to zero and to their counterparts from the "no change' group 
useful to keep in mind that earnings for year -1 actually belong to the same annual report as dividends declared in year 0). Dividend decreases and omissions are associated with significant earnings decreases. Dividend increases are associated with earnings increases - and the median of the earnings changes increases for each successive quintile. For the group of companies that do not change their dividends, earnings actually decrease from year -2 to year -1 . The mean is significantly negative at a $5 \%$ level. One should be careful, however, when interpreting the results of the mean tests, since most of the series used in this section are far from being normal and outliers seem to be a problem. Thus, non-parametric tests for the equality in medians should be more accurate and are used throughout the section.

Companies that resume dividend payments also enjoy a significant increase in earnings. The only "exception to the rule" are companies that did not pay dividends in either year -1 or year 0 - the non-payment decision comes in spite of a significant earnings increase.

To sum up, dividends seem to "predict" the past rather than the future. This challenges the idea that dividend increases are good news because they are a (costly) signal for faster subsequent earnings growth.

There may, however, be other mechanisms that make dividend changes good or bad news. One possibility is that dividend changes become informative due to managers' reluctance to decrease dividends.

In his classical study, Lintner (1956) wrote that the dividend policy of his time was characterized by "inertia and conservatism" and that "most managements sought to avoid making changes in their dividends that might have to be reversed within a year or so". Almost half a century later, Brav, Graham, Harvey, and Michaely (2004) conducted a survey of 384 financial executives of US firms and found that $94 \%$ of managers try to avoid reducing dividends (this is the highest score in their survey); $88 \%$ agree that there are negative consequences to reducing dividends, while $78 \%$ are reluctant to make a dividend decision that might need to be reversed.

In their paper, Brav et al. (2004) also report that $90 \%$ of managers in their sample say they smooth dividends. They conclude that the managers' perception is that "there is not much reward in increasing dividends but there is perceived to be a large penalty for reducing dividends." A casual look at the Swiss sample suggests that this pattern is to be confirmed. Table 8 presents the dividend changes in year 0 and the corresponding dividend changes in the previous and following years. Dividend increases are gradual: about $60 \%$ of dividend increases are associated with at least a previous or a following increase. When dividends are omitted, there is no dividend payment in three quarters of the following years. This persistence is confirmed by the data on years without dividend payments following dividend omissions. Just like in studies based on US data, dividend increases and years when dividends are not changed vastly outnumber years with dividend decreases and omissions. This pattern can be associated with the investors' preference for successive small positive surprises and isolated large negative surprises, as suggested by Shefrin and Statman (1984). 
Table 8 Dividend payments over successive years

\begin{tabular}{|c|c|c|}
\hline Previous year & Base year & Next year \\
\hline $\begin{array}{l}\text { Dividend decreases: } 4 \\
\text { Resumed payments: } 6 \\
\text { No change: } 22 \\
\text { Dividend increases: } 12\end{array}$ & Dividend omissions: 44 & $\begin{array}{l}\text { Continued omissions: } 33 \\
\text { Resumed payments: } 11\end{array}$ \\
\hline Dividend omissions: 33 & No payments following & Continued omissions: 93 \\
\hline Continued omissions: 84 & omissions: 117 & Resumed payments: 24 \\
\hline $\begin{array}{l}\text { Dividend omissions: } 6 \\
\text { Continued omissions: } 19\end{array}$ & Resumed payments: 25 & $\begin{array}{l}\text { Dividend omissions: } 2 \\
\text { Dividend increases: } 15 \\
\text { No change: } 8\end{array}$ \\
\hline $\begin{array}{l}\text { Dividend decreases: } 10 \\
\text { No change: } 20 \\
\text { Dividend increases: } 23\end{array}$ & Dividend decreases: 65 & $\begin{array}{l}\text { Dividend decreases: } 10 \\
\text { No change: } 23 \\
\text { Dividend increases: } 17 \\
\text { Omissions: } 5\end{array}$ \\
\hline $\begin{array}{l}\text { Dividend decreases: } 25 \\
\text { No change: } 115 \\
\text { Dividend increases: } 105 \\
\text { Resumed pavments: } 6\end{array}$ & No change: 271 & $\begin{array}{l}\text { Dividend decreases: } 22 \\
\text { No change: } 121 \\
\text { Dividend increases: } 103 \\
\text { Dividend omissions: } 24\end{array}$ \\
\hline $\begin{array}{l}\text { Dividend decreases: } 22 \\
\text { No change: } 105 \\
\text { Dividend increases: } 240 \\
\text { Resumed payments: } 16\end{array}$ & Dividend increases: 409 & $\begin{array}{l}\text { Dividend decreases: } 40 \\
\text { No change: } 97 \\
\text { Dividend increases: } 257 \\
\text { Dividend omissions: } 15\end{array}$ \\
\hline
\end{tabular}

Dividends may thus become informative about earnings in a way not envisaged in classical signaling models. Since managers want to avoid dividend decreases, they will only increase dividends when they are reasonably sure that there has been a sustainable increase in earnings. They will also cut or omit dividends only when the firm's earnings position has deteriorated considerably. As a result, a dividend increase will follow a period of significant earnings growth and confirm that the new, higher level of earnings is persistent. At the same time, dividend decreases will follow a slowdown and confirm that the firm will still be in a difficult position in the future. Indeed, although their study seriously challenges the role of dividend changes as a signal for future earnings, Benartzi et al.(1997) find that earnings are less likely to decrease following dividend increases.

One way to check the validity of this hypothesis is to look at the difference between the mean levels of earnings before and after the dividend change. Table 9 presents the results of this comparison. One can see that dividend increases are associated with significant positive shifts in the mean level of earnings. This result is supported by the large majority of the significance tests for each quintile of dividend increases. The difference between the sample of firm-years with dividend decreases and the sample with dividend increases is also quite significant. This result is all the more interesting since the dividend increase group only shows significantly higher growth between years -3 and -2 , and -2 and -1 (between years -1 and 0 , the difference is only significantly larger for the Wilcoxon test). Thus, although the period of remarkable growth 
Table 9 Dividend changes and changes in average earnings

\begin{tabular}{|c|c|c|c|c|c|c|}
\hline Type & Mean & Median & $\begin{array}{l}p \text { value, } \\
\text { mean } \\
\text { compared } \\
\text { to } 0\end{array}$ & $\begin{array}{l}p \text { value, } \\
\text { mean } \\
\text { compared } \\
\text { to the no } \\
\text { change } \\
\text { subsample }\end{array}$ & $\begin{array}{l}p \text { value, } \\
\text { median } \\
\text { compared } \\
\text { to the no } \\
\text { change } \\
\text { subsample } \\
\text { (Wilcoxon } \\
\text { test) }\end{array}$ & $\begin{array}{l}p \text { value, } \\
\text { median } \\
\text { compared } \\
\text { to the no } \\
\text { change } \\
\text { subsample } \\
\left(\chi^{2} \text { test }\right)\end{array}$ \\
\hline Omissions: 44 & 0.01311 & 0.00898 & 0.2821 & 0.1159 & 0.4266 & 0.5001 \\
\hline Continued omissions: 117 & 0.06110 & 0.03114 & 0.0000 & 0.0000 & 0.0000 & 0.0000 \\
\hline Decreases: 65 & -0.00513 & -0.00483 & 0.3445 & 0.6794 & 0.2100 & 0.0726 \\
\hline No change: 271 & -0.00208 & 0.00139 & 0.2492 & & & \\
\hline Increases: Q1: 84 & 0.01201 & 0.00958 & 0.0702 & 0.0464 & 0.0488 & 0.0228 \\
\hline$Q 2: 80$ & 0.00689 & 0.00840 & 0.1629 & 0.1834 & 0.1758 & 0.0389 \\
\hline Q3: 82 & 0.01647 & 0.01179 & 0.0137 & 0.0093 & 0.0095 & 0.0108 \\
\hline$Q 4: 81$ & 0.01369 & 0.01534 & 0.0375 & 0.0027 & 0.0033 & 0.0078 \\
\hline Q5: 82 & 0.02025 & 0.00978 & 0.0481 & 0.0071 & 0.1882 & 0.2995 \\
\hline All increases: 409 & 0.01389 & 0.01132 & 0.0000 & 0.0009 & 0.0010 & 0.0097 \\
\hline Resumed payments: 25 & $\begin{array}{l}0.04830 \\
p \text { value, } \\
\text { mean }\end{array}$ & 0.02785 & $\begin{array}{l}0.1303 \\
p \text { value, } \\
\text { median } \\
\text { (Wilcoxol }\end{array}$ & test) & $\begin{array}{l}0.0314 \\
p \text { value, } \\
\text { median }\left(\chi^{2} \text { test }\right)\end{array}$ & $\begin{array}{l}0.0599 \\
)\end{array}$ \\
\hline $\begin{array}{l}\text { Increases versus } \\
\text { decreases }\end{array}$ & 0.0219 & & \multicolumn{2}{|l|}{0.0015} & \multicolumn{2}{|l|}{0.0000} \\
\hline $\begin{array}{l}\text { Increases versus } \\
\text { resumed payments }\end{array}$ & 0.0213 & & \multicolumn{2}{|l|}{0.0274} & \multicolumn{2}{|l|}{0.0149} \\
\hline $\begin{array}{l}\text { Resumed payments } \\
\text { versus continued omissic }\end{array}$ & ${ }_{\mathrm{is}}^{0.6538}$ & & \multicolumn{2}{|l|}{0.2024} & \multicolumn{2}{|l|}{0.8256} \\
\hline
\end{tabular}

The table presents the relationship between changes in dividends per share and changes in average earnings per share. The earnings indicator is computed as the difference between average earnings per share over years 1 to 3 and the average earnings per share over years -3 to -1 , normalized by total assets per share at the end of year -1 . Observations are grouped according to the sign and the size of the change in dividends per share: omissions, continued omissions (when no dividends are paid following a dividend omission), renewed payments, decreases, no change, and the quintiles of dividend increases

is in the past, a dividend increase seems to guarantee that this growth will not be reversed in the medium term.

The mean and median of the earnings change for the group of dividend decreases are negative, and the $\chi^{2}$ test even suggests significance. However (and although one may claim that insignificance is mainly due to the small size of the subsample of dividend decreases), results do not strongly imply a shift for the worse when dividends go down. Indeed, in the case of dividend omissions, the mean and median are both positive, although the difference in earnings is not significantly different from zero or from the change of the benchmark constant dividend group.

Thus, the bad news contained in the dividend decrease may be that the difficult times for the company will continue in the future and that the firm's 
Table 10 Dividend changes and average earnings

\begin{tabular}{|c|c|c|c|c|}
\hline & & & $\begin{array}{l}p \text { value, } \\
\text { previous } \\
3 \text { years }\end{array}$ & $\begin{array}{l}p \text { value, } \\
\text { following } \\
3 \text { years }\end{array}$ \\
\hline \multirow[t]{6}{*}{ Dividend decreases } & \multirow[t]{3}{*}{ Compared to no change } & Mean & 0.8378 & 0.5972 \\
\hline & & Mean, Wilcoxon test & 0.5279 & 0.1236 \\
\hline & & Median, $\chi^{2}$ test & 0.2539 & 0.0726 \\
\hline & \multirow[t]{3}{*}{ Compared to increases } & Mean & 0.0159 & 0.0009 \\
\hline & & Median, Wilcoxon test & 0.0009 & 0.0000 \\
\hline & & Median, $\chi^{2}$ test & 0.0008 & 0.0000 \\
\hline \multirow[t]{6}{*}{ Dividend omissions } & \multirow[t]{3}{*}{ Compared to no change } & Mean & 0.0000 & 0.1655 \\
\hline & & Mean, Wilcoxon test & 0.0000 & 0.0022 \\
\hline & & Median, $\chi^{2}$ test & 0.0001 & 0.0012 \\
\hline & \multirow[t]{3}{*}{ Compared to increases } & Mean & 0.0005 & 0.0000 \\
\hline & & Mean, Wilcoxon test & 0.0000 & 0.0000 \\
\hline & & Median, $\chi^{2}$ test & 0.0000 & 0.0000 \\
\hline \multirow[t]{6}{*}{ Continued omissions } & \multirow[t]{3}{*}{ Compared to no change } & Mean & 0.0000 & 0.3383 \\
\hline & & Mean, Wilcoxon test & 0.0000 & 0.0003 \\
\hline & & Median, $\chi^{2}$ test & 0.0000 & 0.0000 \\
\hline & \multirow[t]{3}{*}{ Compared to increases } & Mean & 0.0000 & 0.0000 \\
\hline & & Mean, Wilcoxon test & 0.0000 & 0.0000 \\
\hline & & Median, $\chi^{2}$ test & 0.0000 & 0.0000 \\
\hline
\end{tabular}

The table presents the relationship between dividend changes and average earnings levels before and after the change. The measure for the previous average earnings is computed as the ratio between the sum of earnings per share for years -3 to -1 divided by total assets per share at the end of year -1 . The measure for the future average earnings uses the average earnings per share for years $1-3$

management is no longer able to "smooth" dividends. One can look at the profitability of these companies and compare it to that of the other firms. Table 10 shows that profitability is indeed lower for companies that decrease, omit, or continue not to pay dividends. It also seems that the gap becomes wider over time for dividend decreases. While the comparison is a rough one given the overlap between the earnings observations, it does suggest a striking pattern. (Moreover, the problem of overlap is more likely to blur differences between observations rather than increase them).

Therefore dividend decreases, omissions, and continued non-payments are a sign that bad times will continue for the company. There may be even a slight worsening of the firm's position in the case of dividend decreases.

\subsubsection{Dividend changes and cash flows}

It has been argued that earnings numbers are less reliable for Switzerland than for the USA. This may affect the accuracy of the results presented above. One can try to use cash flows as an alternative indicator of firm performance. Cash flow numbers are more difficult to "manage" than accounting earnings, and they are also less likely to be manipulated than "headline" measures such as earnings per share. Moreover, if managers are mainly concerned with their abil- 
ity to honor their commitment for regular cash outlays, cash flows may be more important than accounting earnings.

The results using cash flows are quite similar to those based on earnings per share. Dividend increases are associated with strong past growth in cash flows; cash flow changes remain positive between years -1 and 0 , and 0 and 1 , but the growth is not significantly higher than that of the control group. The mean and median of cash flow changes between years -2 and -1 for the group of dividend decreases are both negative. Moreover, companies that decrease, omit, or continue not to pay dividends generate significantly less cash relative to their total assets, and the gap becomes slightly wider after the dividend change (not

Table 11 Dividend changes and changes in average cash flows

\begin{tabular}{|c|c|c|c|c|c|c|}
\hline Type & Mean & Median & $\begin{array}{l}p \text { value, } \\
\text { mean } \\
\text { compared } \\
\text { to } 0\end{array}$ & $\begin{array}{l}p \text { value, } \\
\text { mean } \\
\text { compared } \\
\text { to the } \\
\text { no change } \\
\text { subsample }\end{array}$ & $\begin{array}{l}p \text { value, } \\
\text { median } \\
\text { compared } \\
\text { to the } \\
\text { no change } \\
\text { subsample } \\
\text { (Wilcoxon } \\
\text { test) }\end{array}$ & $\begin{array}{l}p \text { value, } \\
\text { median } \\
\text { compared } \\
\text { to the } \\
\text { no change } \\
\text { subsample } \\
\left(\chi^{2} \text { test }\right)\end{array}$ \\
\hline Omissions & 0.00119 & -0.00509 & 0.9384 & 0.9544 & 0.3120 & 0.3408 \\
\hline Continued omissions & 0.02260 & 0.01760 & 0.1014 & 0.0451 & 0.0018 & 0.0600 \\
\hline Decreases & $-0.00101-$ & -0.00085 & 0.8600 & 0.8660 & 0.3559 & 0.4898 \\
\hline No change & 0.00050 & 0.00524 & 0.9037 & & & \\
\hline \multicolumn{7}{|l|}{ Increases } \\
\hline$Q 1$ & 0.01166 & 0.01584 & 0.0000 & 0.2144 & 0.0093 & 0.0754 \\
\hline$Q^{2}$ & 0.01849 & 0.02327 & 0.0006 & 0.0291 & 0.0022 & 0.0047 \\
\hline$Q 3$ & 0.02826 & 0.26605 & 0.0000 & 0.0007 & 0.0000 & 0.0001 \\
\hline$Q 4$ & 0.01925 & 0.02519 & 0.0042 & 0.0027 & 0.0012 & 0.0006 \\
\hline$Q 5$ & 0.03022 & 0.01321 & 0.0061 & 0.0021 & 0.0082 & 0.2995 \\
\hline All increases & 0.02153 & 0.02053 & 0.0000 & 0.0001 & 0.0000 & 0.0000 \\
\hline Resumed payments & \multicolumn{2}{|c|}{$\begin{array}{l}p \text { value, } \\
\text { mean }\end{array}$} & \multicolumn{2}{|c|}{$\begin{array}{l}p \text { value, } \\
\text { median (Wilcoxon test) }\end{array}$} & \multicolumn{2}{|c|}{$\begin{array}{l}p \text { value, } \\
\text { median }\left(\chi^{2} \text { test }\right)\end{array}$} \\
\hline $\begin{array}{l}\text { Increases versus } \\
\text { decreases }\end{array}$ & \multicolumn{2}{|l|}{0.0119} & \multicolumn{2}{|l|}{0.0002} & \multicolumn{2}{|l|}{0.0001} \\
\hline $\begin{array}{l}\text { Increases versus } \\
\text { resumed payments }\end{array}$ & \multicolumn{2}{|l|}{0.0254} & \multicolumn{2}{|l|}{0.4068} & \multicolumn{2}{|l|}{0.5365} \\
\hline \multicolumn{7}{|c|}{$\begin{array}{l}\text { Versus } \\
\text { continued omissions }\end{array}$} \\
\hline $\begin{array}{l}\text { Increases versus } \\
\text { Omissions }\end{array}$ & \multicolumn{2}{|l|}{0.0814} & \multicolumn{2}{|l|}{0.0026} & \multicolumn{2}{|l|}{0.0116} \\
\hline
\end{tabular}

The table presents the relationship between changes in dividends per share between year 0 and year 1 and average cash flows. The cash flow indicator is computed as the difference between average cash flows per share over years 1 to 3 and -3 to -1 , normalized by total assets per share at the end of year -1 . Observations are grouped according to the sign and size of the change in dividends per share: omissions, continued omissions (when no dividends are paid following a dividend omission), renewed payments, decreases, no change, and the quintiles of dividend increases. The mean and median earnings ratios for each group are then compared to zero and to their counterparts from the "no change" group 
Table 12 Dividend changes and changes in average capital expenditures

\begin{tabular}{|c|c|c|c|c|c|c|}
\hline Type & Mean & Median & $\begin{array}{l}p \text { value, } \\
\text { mean } \\
\text { compared } \\
\text { to } 0\end{array}$ & $\begin{array}{l}p \text { value, } \\
\text { mean } \\
\text { compared } \\
\text { to the } \\
\text { no change } \\
\text { subsample }\end{array}$ & $\begin{array}{l}p \text { value, } \\
\text { median } \\
\text { compared } \\
\text { to the } \\
\text { no change } \\
\text { subsample } \\
\text { (Wilcoxon } \\
\text { test) }\end{array}$ & $\begin{array}{l}p \text { value, } \\
\text { median } \\
\text { compared } \\
\text { to the } \\
\text { no change } \\
\text { subsample } \\
\left(\chi^{2} \text { test }\right)\end{array}$ \\
\hline Omissions: 33 & -0.02728 & $3-0.01174$ & 40.1309 & 0.0868 & 0.0613 & 0.0385 \\
\hline Continued omissions: 82 & $2-0.06295$ & -0.00970 & 0.0081 & 0.0005 & 0.0009 & 0.0018 \\
\hline Decreases: 52 & -0.00636 & -0.00932 & 0.4147 & 0.8899 & 0.0468 & 0.0315 \\
\hline No change: 197 & -0.00505 & 0.00423 & 0.2526 & & & \\
\hline All increases: 342 & 0.00851 & 0.00630 & 0.0001 & 0.0021 & 0.0168 & 0.5529 \\
\hline Resumed payments: 17 & $\begin{array}{l}0.01172 \\
p \text { value, } \\
\text { mean }\end{array}$ & 0.00635 & $\begin{array}{l}0.0385 \\
p \text { value, } \\
\text { median } \\
\text { (Wilcoxon test) }\end{array}$ & 0.2677 & $\begin{array}{l}0.1928 \\
p \text { value, } \\
\text { median }\left(\chi^{2} \text { test }\right)\end{array}$ & 0.4482 \\
\hline $\begin{array}{l}\text { Increases versus } \\
\text { decreases }\end{array}$ & 0.0185 & & 0.0002 & & 0.0029 & \\
\hline $\begin{array}{l}\text { Increases versus } \\
\text { resumed payments }\end{array}$ & 0.7411 & & 0.7987 & & 0.8129 & \\
\hline $\begin{array}{l}\text { Resumed payments } \\
\text { versus } \\
\text { continued omissions }\end{array}$ & 0.1479 & & 0.0028 & & 0.0029 & \\
\hline $\begin{array}{l}\text { Increases versus } \\
\text { Omissions }\end{array}$ & 0.0001 & & 0.0010 & & 0.0021 & \\
\hline
\end{tabular}

The table presents the relationship between changes in dividends per share between year 0 and year 1 and changes in capital expenditures per share. The change in capital expenditures is computed as the difference between average capital expenditures per share in years 1 to 3 and -3 to -1 , normalized by total assets per share at the end of year -1 . Observations are grouped according to the sign and size of the change in dividends per share: omissions, continued omissions (when no dividends are paid following a dividend omission), renewed payments, decreases, no change, and the quintiles of dividend increases.

reported). Table 11 shows the shift in average cash flows between years -3 to -1 and 1 to 3 . Results are at least as strong as those based on earnings. It can also be noted that the performance of companies omitting dividends seems worse if one uses cash flow numbers rather than earnings numbers. There may be an element of earnings management here - the dip in reported earnings between years -2 and -1 is higher, making the future rebound more significant. As a result, there will be larger but isolated negative earnings changes and small but frequent positive earnings news, as suggested by Shefrin and Statman (1984). The evidence is, however, not very strong and this conclusion must remain tentative.

\subsubsection{Dividend Changes and Capital Expenditures}

It is also interesting to look at the changes in capital expenditures around dividend changes. For instance, if companies generate large cash flows (as it 
seems to be the case before dividend increases), larger dividends may be an instrument used to reduce or prevent overinvestment. Table 12 shows that capital expenditures increase following dividend increases. At the same time, the capital expenditures of companies that keep dividends constant are basically flat, while the capital expenditures of companies that omit or continue not to pay dividends decrease significantly. For the group of companies that decrease dividends, the mean and median for the change in capital expenditures are negative, and the median tests suggest this result is significant. Thus a positive (negative) change in dividends seems to be associated with a positive (negative) change in capital expenditures. (This comparison uses a slightly smaller sample because of limited data availability. The missing observations do not seem to be concentrated in any of the dividend change categories and they are unlikely to affect results.)

By having a closer look at the data, one can also see that companies that declared and paid lower dividends in year 0 had significantly lower capital expenditures in year -1 compared to year -2 . Companies that decreased dividends also seem to have done worse, although the difference is not significant. Companies that increased dividends are basically undistinguishable from the control group. Similar results hold for changes in capital expenditures between years -3 and -2 (the actual numbers are available upon request).

An additional interesting result is that, in a probit regression explaining dividend cuts, a dummy variable for losses has explanatory power over and above that of the relative level of earnings or the earnings changes. These results (available upon request) are in line with the findings of DeAngelo et al. (1992) for a sample of US firms and those of Goergen et al. (2003) for a sample of German firms. The authors confirm the managers' reluctance to cut dividends - a loss is largely a "necessary" condition for dividend cuts.

To summarize the findings of this section, it seems that dividends are increased following sustained growth in terms of earnings and cash flows. While the future performance of dividend-increasing companies is not as impressive, earnings and cash flow remain at a comparatively high level over the medium term. Companies that decrease or omit dividends show a different pattern. Their initial position in terms of their accounting profitability or their capacity to generate cash flows is worse. For companies that omit dividends there is only weak evidence of a limited earnings and cash flow rebound, while for dividend decreases the evolution is slightly negative. Companies that continue not to pay dividends do show some improvement, but the situation of all three groups remains worse than that of dividend- increasing companies over the medium term. Moreover, dividend omissions follow 2 years of sustained reductions in capital expenditures. Years with dividend decreases and zero dividend payments are followed by years with significantly lower capital outlays. Overall, dividend increases seem to be gradual and much more frequent than dividend decreases and omissions. In most cases, companies that omit dividends continue not paying over the following years.

All these elements seem to suggest that managers are averse to dividend cuts, and that they only increase dividends when they are sure that the firm's position 
has improved in a sustainable way. Thus dividend changes become informative for the future: dividend increases show that the positive past performance will not be reversed over the medium term, and dividend decreases and cuts confirm a relatively poor performance during the following years. This mechanism is to some extent related to the model of Fudenberg and Tirole (1996) who show that when managers are risk-averse and more recent information is more important in assessing their performance, the result will be earnings smoothing. When dividends are introduced in the model, both earnings and dividends are smoothed and both contain information.

\subsubsection{Alternative explanations}

Agency theory suggests that dividend increases can be used as a way to force managers to distribute idle cash and avoid overinvestment. Thus the fact that dividends increase for cash-rich companies (dividend increases are associated with higher cash flows and cash levels before the dividend change, not reported) should not come as a surprise.

Other evidence, however, tends to qualify the agency explanation. Capital expenditures increase following dividend increases, and decrease following dividend decreases and omissions compared to the previous average (This is in line with the findings of Yoon and Starks 1995 and Denis et al. 1994). Moreover, companies that increase dividends have not had significantly higher increases in capital expenditure over the previous 2 years, while companies that omit dividends show a significant slowdown over the same period. Thus, dividend increases do not follow an investment boom, while dividend cuts and omissions are not associated with subsequent higher investment that may indicate better growth opportunities. Cash flows and cash levels for dividend-increasing companies remain at a high level and even increase over the medium term.

All this does not mean that agency considerations do not seem to play a role. It may be that dividend increases play a preventive role: given the persistent high cash flows generated by the company and the higher level of future capital expenditure, dividend increases could be used as a way to force managers to keep up the firm's performance in the future. Indeed, this pressure may explain why dividend increases happen at all if one accepts the idea of managers' reluctance to commit to higher payments.

The fact that capital expenditures decrease significantly following dividend omissions and dividend decreases is quite striking. Dividends do not seem to be cut in order to take advantage of new and significant growth opportunities. One may think instead that these firms are constrained and are unable to sustain investment on the previous scale. This may be because external funds are expensive. Fama and French (2001) mention the "pecking order theory" when analyzing the evolution of dividend policy in the USA over the last decades. Using Italian data, Sembenelli (1993) finds that dividends are increased slowly, over several years, while dividend cuts tend to be much more abrupt. He explains this in terms of "financial hierarchy". External funds are expensive, and thus firms will only increase dividends at a moderate pace in order to build financial 
slack. At the same time, they will decrease dividends quickly in order to avoid cutting investment or losing favorable growth opportunities.

The fact that this relationship can be found based on Swiss data is interesting. Indeed, many authors have claimed that bank-dominated financial systems, such as those in continental Europe or in Japan, allow for a better provision of funds for companies as a result of close long-term relationships between financial intermediaries and their customers. In particular, banks in these countries are supposed to help reduce the costs of financial distress by providing liquidity (see for instance Kashyap et al. 1990). While this is a widespread view, there are authors who have challenged this view and argued that the positive role of bank relationships in these countries is overstated. An example in this direction is the comprehensive study of Edwards and Fischer (1996) on the German financial system. The findings in this paper may be taken to suggest that firms that cut dividends are constrained and that they cannot readily access external funds.

There are, however, some caveats that should prevent one from looking at the findings in a pure "pecking order" perspective. First, companies that decrease or omit dividends seem to have done rather poorly over the previous years, and it is doubtful whether they have many valuable investment opportunities. Thus, the lack of support from financial intermediaries may simply be the result of a straightforward decision without too much impact from factors such as asymmetric information. The data also do not fully support the "financial hierarchy" scenario of Sembenelli (1993): when companies omit dividends, they have already lowered their capital expenditures over the previous 2 years. Instead of abruptly cutting dividends in order to benefit from valuable investment opportunities, it seems that managers are willing to forego capital expenditures rather than cut dividends. This is in agreement with the results in the survey of Brav et al. (2004), who show that most managers consider maintaining the dividend level at least as important as investment decisions. Thus, while a "pecking order" phenomenon may be part of the story, it is not the whole story.

Grullon et al. (2002) put forward the "maturity hypothesis". They find that the good news contained in dividend increases is not that earnings will increase faster in the future, but that a systematic decrease will be significantly lower. Thus, while profitability declines following a dividend increase, the decrease in risk more than makes up for it. The situation is symmetric for dividend decreases: while there is a profitability rebound, there is also a significant increase in risk. They then argue that dividend increases may be a sign of "firm maturity": as a firm becomes mature, that is, it is less risky and has fewer growth opportunities, it will naturally disburse more cash to its shareholders.

Again, the fact that capital expenditures rise following dividend increases does not fit the "maturity" explanation. Additionally, one may note that the maturity hypothesis does not provide a clear intuition for the meaning of dividend decreases.

At a more basic level, the findings in this paper and those of Grullon, and Swaminathan are not contradictory. If dividend increases are a sign of lower risk, it is also less likely that the previous good performance of the firm will 
be reversed in the near future - that is, that the mean of future earnings will be lower. Benartzi et al. (1997) also find that companies that increase their dividends are less likely to experience earnings decreases. One can indeed note that "one interesting issue" Brav et al. (2004) find in their interviews "is that some mangers view their information conveyance as being about the mean of the distribution of future earnings, while others believe that information conveyance primarily helps resolve uncertainty and so is about the second moment of the distribution."

The pattern of dividend increases and decreases (as well as that of earnings changes) can also be interpreted as a sign that managers try to present their company in a light that makes it attractive to investors' preferences, as presented in Shefrin and Statman (1984). After all, dividends and earnings per share are the most visible numbers, at least for small individual shareholders. The recent "catering theory" of Baker and Wurgler (2004) shows that managers are indeed sensitive to investor preferences.

Finally, one should keep in mind that the fact that dividend increases are not a harbinger of faster earnings growth does not necessarily condemn the signaling idea. Since the standard signaling models are usually two-period models, one cannot distinguish between faster earnings growth and higher future earnings levels. Indeed, since dividends are usually seen as a signal for permanent earnings, taking averages over several years may actually give a better approximation of permanent earnings. Thus some signaling may also be part of the explanation for dividend changes - albeit not the entire story.

\section{Conclusions}

The paper has examined several features of dividend policy for a sample of Swiss companies. Cross-sectional comparisons show negative relationships between dividend payments and market-to-book ratios, price volatility, and leverage, as well as positive relationships with profitability and (to a lesser extent) firm size and institutional holdings. Ownership concentration does not seem to have significant effects. Companies that used repurchases over the recent years were riskier and less profitable than companies choosing dividends. While some of these relationships are expectable, the negative relationship between leverage and dividend payments, the weak influence of ownership structure, the strong influence of price volatility, and the contrast between dividends and repurchases are not obvious results in the light of theory and previous empirical studies and thus are important aspects to note.

The analysis of dividend decisions over time shows that the classical Lintner model of partial adjustment has a rather mixed performance. A look at changes in dividends per share - the measure that is usually given pride of place in annual reports - reveals interesting patterns, however.

Signaling models suggest that dividend changes predict future profitability. Still, the analysis of the data indicates that when dividends increase, earn- 
ings have already increased. There are no obvious signs of faster growth after positive changes in dividends.

Nonetheless, there is evidence that when dividends increase, future average earnings will be at a higher level compared to the past. Companies that decrease or omit dividends have been in a difficult position for several years, and they will still have inferior cash flows and earnings over the medium term. They will also have significantly lower capital expenditures.

These findings suggest that dividend changes can become informative due to the manager's asymmetric perception of rewards for dividend increases and negative consequences of dividend cuts. Since managers try to avoid cutting dividends until they "have to", and only increase them when they think earnings are sufficient, dividend increases show that earnings have shifted to a higher level over the medium term, while dividend decreases are a sign that the firm's problems are likely to continue in the following years.

This mechanism can also explain why price volatility is such an important factor in the cross-sectional comparisons. If price volatility is taken to be a sign of uncertainty concerning future earnings, then its strong negative relationship with dividends may mean that managers try to keep dividends at a low level in order to avoid having to cut them in low earnings states. Thus, dividend changes can actually be informative, although the mechanism may be different from that considered in classical signaling models. Exploring this hypothesis over larger samples, and perhaps for other countries with different regulatory environments, can be an interesting area for future research.

Acknowledgements The author would like to thank Michel Habib and two anonymous referees for their very useful comments.

\section{References}

Allen, F., Michaely, R.: Payout policy, April. http://ssrn.com/abstract=309589 (2002)

Allen, F., Bernardo, A.E., Welch, I.: A theory of dividends based on tax clienteles. J. Financ. 55, 2499-2536 (2000)

Baker, M., Wurgler, J.: Appearing and disappearing dividends: the Link to catering incentives. J. Financ. Econ. 73, 271-288 (2004)

Benartzi, S., Michaely, R., Thaler R.: Do changes in dividends signal the future or the past? J. Financ. 52, 1007-1034 (1997)

Bhattacharya, S.: Imperfect information, dividend policy, and "The Bird in the Hand" fallacy. Bell J. Econ. 10, 259-270 (1979)

Brav, A., Graham, J.R., Harvey, C.R., Michaely, R.: Payout policy in the 21st century NBER Working Paper No. 9657 (2004)

DeAngelo, H., DeAngelo, L., Skinner, D.J.: Dividends and losses. J. Financ. 47, 1837-1863 (1992)

DeAngelo, H., DeAngelo, L., Skinner, D.J.: Reversal of fortune: dividend signalling and the disappearance of sustained earnings growth. J. Financ. Econ. 40, 341-371 (1996)

DeAngelo, H., DeAngelo, L., Stulz, R.: Dividend policy, agency costs, and earned equity Working Paper, Ohio State University (2004)

Denis, D.J., Denis, D.K., Sarin, A.: The information content of dividend changes: cash flow signaling, overinvestment, and dividend clienteles. J. Financ. Quant. Anal. 29, 567-587 (1994)

Dumont, P.-A., Isakov, D., Perignon C.: Stock repurchase on a second trading line Working paper, HEC-University of Geneva (2004)

Easterbrook, F.H.: Two agency-cost explanations of dividends. Am. Econ. Rev. 74, 650-659 (1984) 
Edwards, J., Fischer, K.: Banks, Finance and Investment in Germany. Cambridge University Press. (1996)

Fama, E.F., French K.R.: Disappearing dividends: changing firm characteristics or lower propensity to pay? J. Financ. Econ. 60, 3-43 (2001)

Fudenberg, D., Tirole J.: A theory of income and dividend smoothing based on incumbency rents. J. Political Econ. 103, 75-93 (1996)

Goergen, M., Renneborg, L.. Correia da Silva L.: When do German firms change their dividends? ECGI Working Papers in Finance, No. 13/2003, February (2003)

Grinstein, Y., Michaely, R.: Institutional holdings and payout Policy. J. Financ. 60, 1389-1426 (2005)

Grullon, G., Michaely, R., Swaminathan, B.: Are dividend changes a sign of firm maturity? J. Bus. $75,387-424$ (2002)

Grullon, G., Michaely, R.: Dividends, share repurchases, and the substitutions hypothesis. J. Financ. 57, 1649-1684 (2002)

Grullon, G., Michaely, R., Benartzi, S., Thaler, R.H.: Dividend changes do not signal changes in future profitability. J. Bus. (in press) (2003)

Guay, W., Harford, J.: The cash-flow permanence and information content of dividend increases versus repurchases. J. Financ. Econ. 57, 385-415 (2000)

Hadjinicolaou, G., Kalay, A.: Wealth redistributions or changes in firm value: an analysis of returns to bondholders and stockholders around dividend anouncements. J. Financ. Econ. 13, 35-63 (1984)

Healy, P.M., Palepu, K.G.: Earnings information conveyed by dividend initiations and omissions. J. Financ. Econ. 198(21), 149-175 (1988)

Jagannathan, M., Stephens, C.P., Weisbach, M.S.: Financial flexibility and the choice between dividends and stock repurchases. J. Financ. Econ. 57, 355-384 (2000)

John, K., Williams, J.: Dividends, dilution, and taxes: a signalling equilibrium. J. Financ. 40, 1053$1070(1985)$

Johnson, S.A.: Dividend payout and the valuation effects of bond announcements. J. Financ. Quant. Anal. 30, 407-423 (1995)

Kashyap, A., Hoshi, T., Scharfstein, D.: The role of banks in reducing the costs of financial distress in Japan. J. Financ. Econ. 27, 67-88 (1990)

La Porta, R., Lopez-de-Silanes, F., Shleifer, A.: Agency problems and dividend policies around the World. J. Financ. 55, 1-33 (2000)

Lintner, J.: Distribution of incomes of corporations among dividends, retained earnings, and taxes. Am. Econ. Rev. 46, 97-113 (1956)

Lang, L., Litzenberger, R.H.: Dividend announcements: cash flow signalling vs. free cash flow hypothesis. J. Financ. Econ. 24, 181-192 (1989)

Maxwell, W.H., Stephens, C.P.: The wealth effects of repurchases on bondholders. J. Financ. 58(2), 895-919 (2003)

Miller, M.H., Modigliani, F.: dividend policy, growth, and the valuation of shares. J. Bus. 34, 411-413 (1961)

Miller, M.H., Rock, K.: Dividend policy under asymmetric information. J. Financ. 40, 1031-1051 (1985)

Nissim, D., Ziv, A.: Dividend changes and future profitability. J. Financ. 2111-2133 (2001)

Osobov, I.: Why are dividends disappearing: an international comparison. 2004 FMA annual meeting, New Orleans, October (2004)

Penman, S.H.: The predictive content of earnings forecasts and dividends. J. Financ. 38, 1181-1199 (1983)

Sembenelli, A.: Signalling, financial hierarchy and agency theory as explanations for dividend behaviour: evidence from Italian firm data. Manag. Decis. Econ. 14, 37-45 (1993)

Shefrin, H.M., Statman, M.: Explaining investor preference for cash dividends. J. Financ. Econ. 13, 253-282 (1984)

Watts, R.: The information content of dividends. J. Bus. 46, 191-211 (1973)

Yoon, P.S., Starks, L.T.: Signaling, investment opportunities, and dividend announcements. Rev. Financ. Stud. 8, 995-1018 (1995) 


\section{Author Biography}

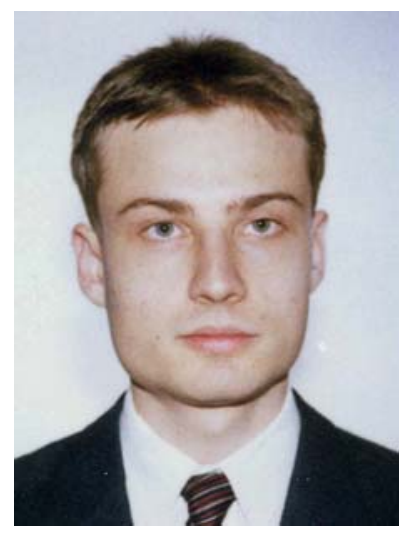

Bogdan Stacescu is a PhD student in Finance at the University of Zurich. Previously he studied at the Central European University in Budapest, Hungary, where he received his MA in Economics in 2003. His research interests include Banking, Corporate Finance, Institutional Economics, Microeconomics, and Game Theory. 